This conception of old drainage systems running parallel to the contours of the mainland, in Cumberland, Haddingtonshire, S.E. Ireland, Denbighshire, Flintshire, etc., when coupled with the warping movements necessary to explain the steep fall of the channels, sets the mind, no less than the land, awhirl.

Bernakd Smith.

\title{
THE GEOLOGICAL AGE OF THE CARRARA MARBLES.
}

Sir,-Permit me to comment briefly on Dr. Du Riche Preller's paper on the Carrara Marble District. ${ }^{1}$ It contains a quantity of interesting information, topographic and economic, but does little, in my opinion, to settle the question as to the age of those rocks or strengthen the position of the Italian geologists. I had their map with me in the autumn of 1889, and in regard to faults (which Dr. Preller considers to be almost negligible) wrote thus in my diary : "In order to accept the geological succession they have indicated, we must explain the proximity of ordinary dark mechanically disturbed limestone (just like some of that at Spezzia) with lighter varieties to perfectly typical Carrara marble." I was aware that the statuary marble is intercalated with marbles of inferior quality, but instead of finding any sign that the metamorphism was a result of pressure, maintain that, as shown by the microscope, that marble has escaped (as I stated) from the crushing which has affected its associates. As to 'metamorphism' and its effect on sedimentary rocks, I have been doing my best to study the whole question since about 1875 , have spent much time and money in examining alleged passages from crystalline schists to comparatively unaltered sediments or intercalations of the $t w o$, with the invariable result that the evidence was nerer conclusive and very commonly worthless; in fact, $I$ have not been able to discover any case (I have not restricted myself to the Alps) where a truly crystalline limestone, such as that of Carrara, is in stratigraphical sequence with a sedimentary rock to which a date can be assigned on the evidence of fossils, except in the case of contact metamorphism, which, so far as I am aware, is not exhibited in the Apuan Alps. Dr. Preller's paper contains no evidence that he has made use of the microscope in studying these Carrara rocks, and as I know the vague use of the term 'schist' by many Continental and some British geologists I am unable to discuss his sections (Figs. I-IV) beyond saying that only one of them seems to demand an explanation, and this I think my past experience would enable me to supply.

T. G. Bonner.

\section{RENÉ ZEILLER-MASTER PALæOBOTANIST.}

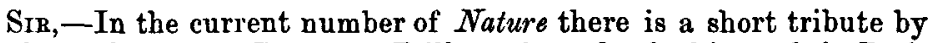
Professor Seward to Professor Zeiller, whose death this week in Paris we all deplore. I should like to add a word in token of the deep and lasting affection and reverence the great Palæobotanist inspired in his younger colleagues in many countries.

\footnotetext{
${ }^{1}$ Geol. MAG., December, 1915, pp. 554-65.
} 
Long before I had personally met him, his work, so deep, so wide, so balanced, so exceptionally thorough, had proclaimed him to me as the master palæobotanist of our time. Professor Seward has referred to his magnificent memoir on the fossil flora of Tonkin: it is, I think, the most perfect piece of palæobotanical work extant-the most perfect in not only containing conclusions of far-reaching and profound significance, but in being the freest from the minor defects of misapprehensions, of carelessnesses, misquotations, and incomplete or incorrect references which are present in nearly all work and abound in some.

It was on visiting Professor Zeiller in Paris, however, that the full extent of his work became apparent to me. The wonderful collection of fossil plants which he had brought together and so intimately knew is, in some respects, unsurpassed and is invaluable to students. Then, too, Professor Zeiller held a unique position in relation to practical mining, and was the guide, philosopher, and friend of Government Departments and coal-miners in a way which is almost unimaginable in this country, where palæobotanists are held in little honour and are put to little practical use. His prescience, based on detailed palæobotanical knowledge, saved his country many tens of thousands of pounds.

But surpassingly in Paris did the enchanting personality of the great man become apparent. Unique were his generosity, his sincerity, his aristocratic and beautiful courtesy and helpfulness towards the younger workers, at whose service he placed the whole storehouse of his profound and well-balanced knowledge. Even in Berlin, where I have heard nearly every other palæobotanist roundly abused, Zeiller -Frenchman though he was-was spoken of with affection and respect.

It is due only to the fact that Professor Zeiller worked in the 'Cinderella' science of palæobotany instead of in some popular and widely respected science like chemistry that his death is not universally hailed by the general public as the irreparable loss it is. To us who knew and loved him, as to his colleagues all over the world, no one can replace René Zeiller.

Marie C. Stopes,

14 WeLl Walik,

Lecturer in Palæobotany, University College, London.

HaMpstEAd HEATH, N.W. December 10, 1915.

OBITUARY.

ARTHUR VAUGHAN, M.A., D.Sc., F.G.S., LeCtURer in Geologt of the UnIversttr of Osford.

WE regret to record the death of Dr. Arthur Vaughan, which occurred on Friday, December 3, 1915, at 315 Woodstock Road, Oxford, in his 47 th year. We hope to give a notice of his geological work in the next number of the Magazine. 